\title{
Santral Dev Hücreli Granülomun Konservatif Tedavisi : Olgu Sunumu
}

\author{
Conservative Treatment of Central Giant Cell Granuloma : Case Report
}

\author{
Berfin Lara IŞIK $\bullet$, Cem TANYEL
}

$\ddot{O} z$

Santral dev hücreli granülomlar sıklıkla maksilla ve mandibulada görülen neoplastik özelliği olmayan fibröz lezyonlardır. Agresif ve agresif olmayan olacak şekilde 2 çeşidi bulunur. Hastalığın tedavisinde, cerrahi tedavilerin yanı sıra konservatif olarak çeşitli seçenekler uygulanmaktadır. İntralezyonel steroid, kalsitonin, interferon uygulanması tedavi seçenekleri arasında gösterilmektedir. Çok sayıda çalışma intralezyonel steroid uygulanmasının başarısını vurgulamıştır. Kliniğimize başvuran 36 yaşında kadın hastanın radyolojik ve klinik muayenesi sonucunda sağ alt çenesinde radyolüsent lezyon tespit edilmiştir. Yapılan biyopsi sonucunda santral dev hücreli granülom tanısı doğrulanmış ve hastanın bilgisi dahilinde ilgili alana intralezyonel steroid enjeksiyonu ile konservatif tedavi uygulanması amaçlanmıştır.

Anahtar Kelimeler: Santral dev hücreli granülom; Konservatif tedavi; İntralezyonel steroid enjeksiyonu

\begin{abstract}
Central giant cell granulomas are non-neoplastic fibrous lesions that are observed in the maxilla and mandible. There are 2 types as aggressive and non-aggressive. Various conservative treatment options are used in addition to surgical treatments. Intralesional steroid, calcitonin, interferon applications are among the treatment options. Previous studies have emphasized the success of injection of intralesional steroids. Radiolucent lesion was determined in the right mandible of a 36-year-old female patient who admitted to our clinic, as a result of radiological and clinical examination. As a result of the biopsy, the diagnosis of central giant cell granuloma was confirmed. It is aimed to perform conservative treatment with intralesional steroid injections to the relevant area within the knowledge of the patient.
\end{abstract}

Berfin Lara Işık (西)

İstanbul Üniversitesi Diş Hekimliği Fakültesi Ă̆ız, Diş ve Çene Cerrahisi Anabilim Dall

e-mail: berfinlara7@gmail.com

Cem Tanyel

İstanbul Üniversitesi Diş Hekimliği Fakültesi Ağız, Diş ve Çene Cerrahisi Anabilim Dall

Submitted / Gönderilme: 09.05.2021

Accepted/Kabul: 18.08.2021
Keywords: Central giant cell granuloma; Conservative treatment; Intralesional steroid injection

\section{Giriş}

Santral dev hücreli granülom benign özellikte nonodontojenik bir lezyondur. Çenelerde görülen benign huylu tümörlerin \%7 sini oluşturur (Kudva et al., 2018). Erkeklere oranla kadınlarda 2 kat daha fazla görülür. Mandibulada 1.büyük azı dişine kadar olan anterior bölge en sık etkilenen yerdir. Genellikle ağrısız şişlikle karakterizedirler fakat hızlı ve yıkıcı bir şekilde büyüyen ve alveolar kemiği yıkıma uğratan vakalar da belirtilmiştir. Ekspansiv ve invaziv olmalarına rağmen sinir çevresindeki yapıları içermediği için parestezi genellikle bu hastalarda gözlenmez (Goyal et al., 2014). Etiyolojisi bilinmemesine rağmen lokal travma ile ilişkili, gelişimsel rahatsızlık, inflamatuar bir lezyon ya da gerçek bir tümör olabileceği belirtilmiştir (Daroit et al., 2017). Çeşitli derecelerde başarılarla sonuçlanan çok sayıda tedavi seçenekleri mevcuttur. Lezyonun cerrahi tedavisi rekürrens olasılığının azaltılması açısından geleneksel olarak kabul görmüş yöntemdir. Cerrahi olmayan tedaviler arasında gösterilen alfa-interferon, kalsitonin, denosumab ve kortikosteroid enjeksiyonları da destekleyici ve/veya kesin tedaviler olarak literatürlerde yerini almıştır (Carlos \& Sedano, 2002; D et al., 2016; Kudva et al., 2018; RL et al., 2010; Silva et al., 2012).

\section{Olgu Sunumu}

36 yaşında kadın hasta İstanbul Üniversitesi Diş Hekimliği Fakültesi'ne diş tedavisi nedeniyle başvurmuştur. Yapılan rutin klinik muayenesinde hasta sağ tarafta belli aralıklarla oluşan uyuşukluk şikayetini dile getirmiş̧ir. Yapılan 
radyografik incelemeler sonucunda ise sağ mandibular premolar bölgesinde radyolüsent lezyon tespit edilmiştir ( Şekil 1). İlgili alanda yapılan insizyonel biyopsi sonucu, santral dev hücreli granülom olarak bildirilmiştir (Şekil 2A 2B). Hipertroidizmde görülen, santral dev hücreli granülomla aynı histolojik özellikler gösteren çene tümörlerinin ayırıcı tanısının yapılması amacıyla hastadan serum pth ve kalsiyum değerleri istenmiştir. Normal olarak gelen değerler biyopsi sonucunu doğrulamıştır. Hastanın yaşı, lezyonun boyutu ve cerrahi tedavinin yaratabileceği post operatif sonuçlar değerlendirilmiş ve hastaya medikal tedavi uygulanması tercih edilmiştir. Hastanın bilgisi dahilinde yazılı onam alındıktan sonra intralezyonel kortikosteroid enjeksiyonu yapilmasına karar verilmiştir. İlgili bölgenin infiltratif anestezisini takiben kenacort-a, sadece kanin ve 1.küçük azı dişinin arasında bulunan lezyonun içine 5 ml'lik şırınga kullanılarak enjekte edilmiştir. Enjeksiyonlar 2 haftalık aralıklarla toplam 3 defa uygulanmıştır. Hastanın tedavisinin 4. ayında şikayetlerinde azalma olduğu gözlenmiştir. Hastanın periyodik kontrolünün 2. yılında iyileşmeye dair olumlu etkiler gözlenmiştir. Hastanın düzenli kontrollerine devam edilmektedir ( Şekil 3).

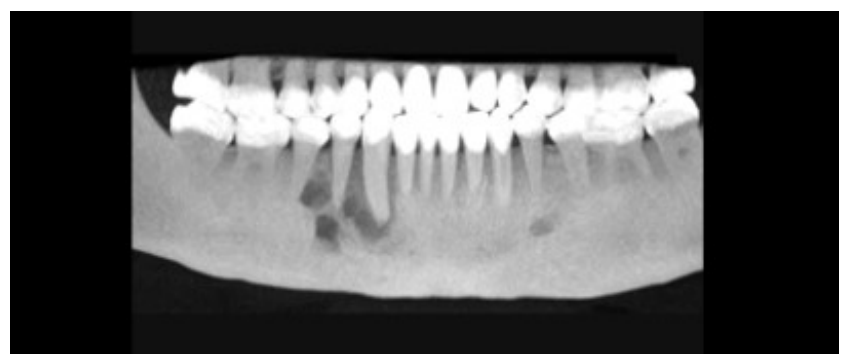

Şekil 1. Sağ mandibulada premolar bölgesinde yer alan radyolüsent lezyonun röntgen görüntüsü

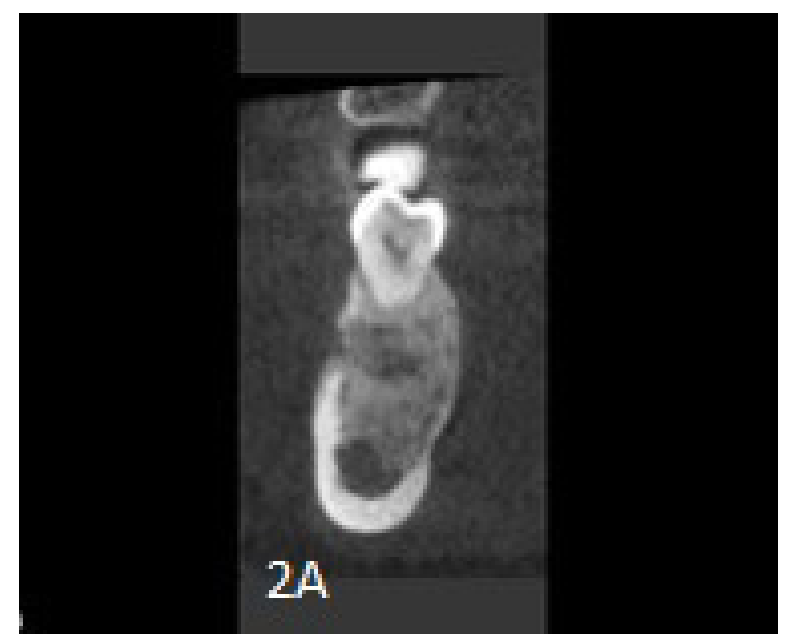

Şekil 2A. Lezyon ile ilişkili bölgenin premolar diş hizasındaki transplanar kesit görüntüsü

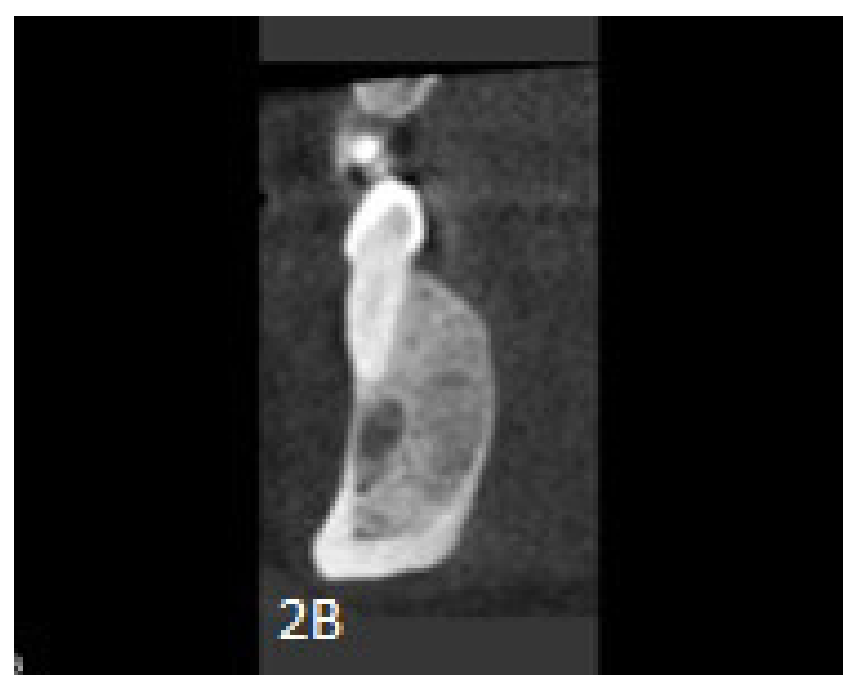

Şekil 2B. Lezyon ile ilişskili bölgenin kanin diş hizasındaki transplanar kesit görüntüsü

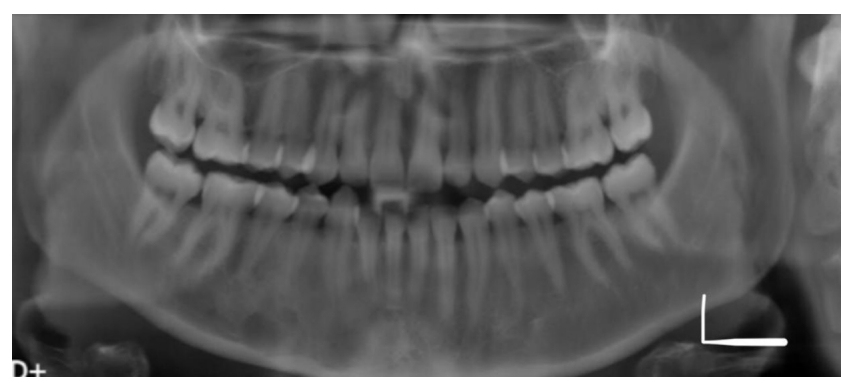

Şekil 3. Tedaviden 2 yıl sonrasında alınan panoramik röntgen görüntüsü

\section{Tartıșma}

Santral dev hücreli granülom neoplastik özellik göstermeyen, kaynăg 1 belli olmayan, agresif bir tutum sergileyebilen osteolitik lezyonlardır. Benign özellikte olmasına rağmen yıkıcı etkiler de gösterebilirler (Goyal et al., 2014). Radyografik ve histolojik özelliklerine bakılarak agresif ve agresif olmayan olarak iki alt tipe ayrilabilir. Agresif tip genellikle genç yetişkinlerde gözükür, kemikte ekspansiyon yapar ve rekürrens olasılığı yüksektir. Agresif olmayan tpi ise asemptomatiktir ve ağrısız şişlikle karakterizedir. Fakat bu iki tip arasında histolojik olarak bir farklılık bulunmamaktadır (Aoki et al., 2012). Çok çekirdekli dev hücreler histolojik olarak vasküler stromada ve sıklıkla yeni kemik oluşumunun olduğu yerde gözlenir. Osteoklast benzeri bu dev hücreler düzensiz bir dağ $11 \mathrm{~m}$ gösteririler ve genellikle kanamanın olduğu alanlarda 
bulunurlar. Çenelerde görülen, dev hücrelerden zengin lezyonlar arasında çerubizm, anevrizmal kemik kisti ve hipertiroidizmde görülen çene tümörleri (brown tümörü) de mevcuttur. Santral dev hücreli granülomda damarların çevresinde oluşan birikintilerin çerubizmde oluşmaması iki lezyonun ayırt edilmesinde etkilidir. Anevrizmal kemik kistinde geniş kan alanları mevcuttur. Hiperparatroidizmde görülen brown tümöründen ayırt edilmesinde ise santral dev hücreli granülomda serum kalsiyum, paratroid hormonu, alkalin fosfataz ve fosfor düzeylerinin normal olması belirleyici faktörler olarak kullanılır. Genellikle tek başına küretaj ya da küretajla birlikte periferal ostektomi en sık kullanılan ve kabul görmüş konservatif cerrahi tedavi seçenekleri arasındadır. Agresif santral dev hücreli granülomun tedavisinde bazen radikal cerrahi seçenekleri olarak periferal ostektomiyle birlikte blok rezeksiyon da belirtilmiştir. $\mathrm{Bu}$ tedaviler yüzde deformitelere, diş kayılarına sebep olabilir. Bu nedenle lezyonun gerilemesi veya eliminasyonu için invaziv cerrahi prosedürlerin daha az uygulanması adına alternatif tedavi yöntemleri geliştirilmiştir (Carlos \& Sedano, 2002; EN et al., 2005; Goyal et al., 2014). Yeni medikal tedavi alternatiflerinin araştırılması ya da cerrahi tedaviye ek tedavi seçeneklerinin uygulanmak istenmesiyle olası bir rezeksiyonun önüne geçilmek istenmiştir (El Hadidi et al., 2015). İntralezyonel kortikosteroid injeksiyonu, alfa interferon ve kalsitonin uygulaması en çok kullanılan yöntemler arasındadır. İntralezyonel injeksiyonların tercih edilmesinin en önemli nedenleri arasında dokularda belli konsantrasyonlarda birikebilmeleri olarak belirtilmiştir. Kortikosteroid tedavisinde lezyonların gerileme sebebinin santral dev hücreli granülomdaki çok çekirdekli dev hücrelerinde ve tek çekirdekli stroma hücrelerinde bulunan glukokortikoid reseptörleri olabileceği belirtilmiştir (Ferretti \& Muthray, 2011; Goyal et al., 2014).

Daroit ve ark. yaptıkları çalışmalarında santral dev hücreli granülomun tedavi seçeneklerini karşılaştırmışlardır. Cerrahi tedavi seçenekleri arasında küretajın, non-agresif lezyonlarda \% 11-49 oranında yüksek rekürrens oranı gösterdiğini; cerrahi rezeksiyonun ise agresif ama rekürrens oranı düşük tedavi seçeneği olduğunu belirtmişlerdir. Çalışmalarında cerrahi tedavi seçenekleri yerine alternatif konservatif tedavi seçeneklerinin kullanılabileceğini belirtmişlerdir. Kalsitonin uygulaması ve intralezyonel kortikosteroid enjeksiyonunun iyi sonuçlar veren, noninvaziv teknikler olduğunu vurgulamışlardır (Daroit et al., 2017).
Kudva ve ark. yaptıkları çalışmalarında cerrahi tedavi seçeneklerinin yanı sıra farmokolojik alternatif tedavilerin de seçenek olarak kullanılabileceğini belirtmişlerdir. İntralezyonel kortikosteroid enjeksiyonunun uygulama kolaylığı, minimal invaziv yaklaşım sergilemesi ve tedavi süresinin kısa olması gibi avantajlarını vurgulamışlardır (Kudva et al., 2018).

Goyal ve ark. ise yaptıkları çalışmalarında intralezyonel kortikosteroid enjeksiyonunun, özellikle çocuklarda, kolay uygulanabilir ve minimal invaziv bir tedavi seçeneği olduğunu vurgulamışlardır. Ekonomik açıdan avantajlı olması, anatomik yapıların korunması ve ciddi yüz deformitelerinin önüne geçilmesini sağlayan iyi bie tedavi seçeneği olduğunu belirtmişlerdir (Goyal et al., 2014).

\section{Sonuç}

Santral dev hücreli granülomlar, sıklıkla mandibula anterior bölgede görülen neoplastik özelliği olmayan lezyonlardır. Tedavisinde cerrahi girişimlerin yanı sıra konservatif medikal tedaviler de uygulanabilmektedir. İntralezyonel kortikosteroid enjeksiyonu bu vakada iyileşmeye dair olumlu sonuçlar elde edilmesini sağlamıştır. Morbidite riskinin en aza indirilmesi ayrıca konservatif yaklaşım sergilenerek sert ve yumuşak dokuların korunması yöntemin avantajları arasındadır.

\section{Kaynaklar}

1. Aoki, T., Karakida, K., Sakamoto, H., Yamazaki, H., Otsuru, M., Sasaki, M., Sakamoto, Y., Aoyama, K. ichi, Ota, Y., \& Kaneko, A. (2012). Successful treatment by intralesional steroid injection in management of central giant cell granuloma of the jaw-report of two cases. Journal of Oral and Maxillofacial Surgery, Medicine, and Pathology, 24(4), 213-217. https://doi.org/10.1016/j.ajoms.2011.11.007

2. Carlos, R., \& Sedano, H. O. (2002). Intralesional corticosteroids as an alternative treatment for central giant cell granuloma. Oral Surgery, Oral Medicine, Oral Pathology, Oral Radiology, and Endodontics, 93(2), 161166. https://doi.org/10.1067/moe.2002.119971

3. D, D., A, E., A, M., \& K, I. (2016). Management of central giant cell granuloma of the jaws with intralesional steroid injection and review of the literature. Oral and Maxillofacial Surgery, 20(2), 203-209. https://doi.org/10.1007/ S10006.015.0530-5

4. Daroit, N. B., de Marco, R. G., Sant'Anna Filho, M., \& Fritscher, G. G. (2017). The challenge in the treatment of central giant cell granuloma - What is the best approach? Journal of Oral and Maxillofacial Surgery, Medicine, 
and Pathology, 29(2), 122-128. https://doi.org/10.1016/j. ajoms.2016.05.009

5. El Hadidi, Y. N., Ghanem, A. A., \& Helmy, I. (2015). Injection of steroids intralesional in central giant cell granuloma cases (giant cell tumor): Is it free of systemic complications or not? A case report. International Journal of Surgery Case Reports, 8, 166-170. https://doi.org/10.1016/j.ijscr.2015.02.001

6. EN, A., LC,A.,AS, R., RA, M., \& RS, G. (2005). Treatment of a central giant cell granuloma with intralesional corticosteroid. The British Journal of Oral \& Maxillofacial Surgery, 43(1), 74-76. https://doi.org/10.1016/J.BJOMS.2004.08.015

7. Ferretti, C., \& Muthray, E. (2011). Management of central giant cell granuloma of mandible using intralesional corticosteroids: Case report and review of literature. Journal of Oral and Maxillofacial Surgery, 69(11), 2824-2829. https://doi.org/10.1016/j.joms.2010.11.020

8. Goyal, P., Narula, R., Bansal, S., Bansal, S., \& Garg, P. (2014). Conservative nonsurgical treatment of mandibular central giant cell granuloma in an adolescent: A case report. Pediatric Dental Journal, 24(1), 58-62. https://doi. org/10.1016/j.pdj.2013.12.002

9. Kudva, A., Cariappa, K. M., Dhara, V., \& Solomon, M. (2018). Central giant cell granuloma: An uncommon presentation. Oral and Maxillofacial Surgery Cases, 4(4), 135-140. https://doi.org/10.1016/j.omsc.2018.08.001

10. RL, N., RC, T., RB, C., RA, R., \& SH, R. (2010). Intralesional injection of triamcinolone hexacetonide as an alternative treatment for central giant-cell granuloma in 21 cases.

11. International Journal of Oral and Maxillofacial Surgery, 39(12), 1204-1210. https://doi.org/10.1016/J. IJOM.2010.06.015

12. Silva, N. G. da, Carreira, A. S. D., Pedreira, E. N., Tuji, F. M., Ortega, K. L., \& Pinheiro, J. de J. V. (2012). Treatment of central giant cell lesions using bisphosphonates with intralesional corticosteroid injections. Head \& Face Medicine 2012 8:1, 8(1), 1-6. https://doi.org/10.1186/1746-160X-8-23 